\title{
THE STRATEGY ANALYSIS FOR PATROL ELEMENTS ADDITION OF BRAVO NAVAL BASE TO SUPPORT MARINE SECURITY OPERATIONS AT INDONESIA ARCHIPELAGIC SEA LANES I
}

\author{
Panji Suwarno ${ }^{1}$, Manahan Budiarto Pandjaitan ${ }^{2}$ Gunardi $^{3}$ \\ 1 Lecturer of Indonesia Defense University, UNHAN Jakarta Indonesia \\ 2 Officer Student of Indonesia Naval Command and Staff College, Seskoal Jakarta Indonesia \\ 3 Head of Operations Department, Seskoal Jakarta Indonesia
}

\begin{abstract}
Indonesian Navy is tasked with enforcing the law and maintaining security in the national jurisdictional sea area following the provisions of national law and international law that have been ratified. To carry out these basic tasks to run well, it is necessary to have support from the Naval Base which is quite accommodating in terms of service and logistical support. The problem in this research is how to compile the strategy analysis for patrol elements addition of Bravo Naval Base to support marine security operations at Indonesia Archipelagic Sea Lanes 1. The purpose of this study was to determine the optimum function of the patrol element of base owned by Bravo Naval Base in support of marine security operations in the Indonesian Archipelago Sea Lanes 1. The method used in this study is Qualitative Descriptive methods by NVivo Software and SWOT analysis methods. The results of this study are the continuation strategies analysis for patrol elements addition of Bravo Naval Base to support marine security operations, and it needs to be a concern and needs to be improved by Indonesian Navy.
\end{abstract}

Keywords: Strategy Analysis, Patrol Element Additions, Bravo Indonesia Naval Base.

\section{INTRODUCTION}

The Indonesian Navy is tasked with enforcing the law and maintaining security in the national jurisdictional sea area under the provisions of national law and international law that have been ratified (Dwi, 2018). To carry out these basic tasks to run well, it is necessary to have support from the Naval Base that is quite accommodating in terms of service and logistical support (Heribertus, Budiyanto, \& Riduwan, 2018). Upholding the law and maintaining security are all forms of activities related to law enforcement at sea in accordance with the authority of the Navy, which are universally applicable and in accordance with applicable laws and regulations to deal with threats of violence, navigation threats and violations of the law in the national jurisdictional sea area (Pujiyono, 2015).

Thus, to provide the best support for all elements that rely on the Bravo Naval Base, it is necessary to be equipped with a variety of good facilities so that the service of the elements does not disappoint so that the elements can carry out their basic tasks properly. Bravo Naval
Base has not been able to provide support and services to the elements properly, this is because it still faces various obstacles, namely the lack of adequate infrastructure. As we know, Bravo Naval Base does not yet have a fuel oil storage tank, and still uses tank vehicles to supply fuel oil support, it will hamper speed, effectiveness, and smoothness in support of elements or warship. The lack of fuel support was very detrimental and hampered elements or warship in carrying out routine activities in the form of security patrols in the Indonesian Archipelago Sea Lanes I (ALKI I) sea and surrounding areas.

To be able to support well the elements or warships that will carry out the provision, the Bravo Naval Base should complement adequate facilities and infrastructure and increase the number of elements or ships to be able to maintain the sovereignty area around ALKI I. The lack of infrastructure facilities and limited elements which is owned by Bravo Naval base, it causes supervision in the sea around ALKI I to be less than optimal, as a result there are many violations around ALKI I. These violations 
include sightings, illegal logging, illegal fishing, terrorism, illegal mining, and others. Bravo Province is crossed by the Indonesian archipelago sea Lanes namely ALKI I which is an archipelago sea Lanes connecting the South China Sea, Natuna Sea, Karimata Strait, Java Sea, and Sunda Strait. For this reason, strict supervision and safeguards need to be carried out to reduce and control sea pollution and various other disturbances in ALKI I, because ALKI I is a very congested shipping sea Lanes for traffic and ships

Based on the data and facts of the condition of infrastructure facilities as well as existing human resources, faced with the size of the work area that is the responsibility of Bravo Naval base, then in accordance with the main tasks and functions of Bravo Naval base in carrying out its base role, namely to support elements or Warships in carrying out marine security operations in ALKI I are still not optimal, this is due to the limited facilities and infrastructure owned by Bravo Naval base is very limited, including the unavailability of piers to dock and anchor elements or warships.

This paper has many kinds of literature to support the research, such as literature with title Maritime Security-Perspectives for a Comprehensive Approach (Feldt, Roell, \& Thiele, 2013), Regional Maritime Cooperation in Maintaining Maritime Security and Stability: A Test Case for ASEAN Unity and Centrality (Mustika \& Aditya, 2017), Learning from Piracy: Future Challenges of Maritime Security Governance (Bueger, 2015), Surveillance And Canadian Maritime Domestic Security (Avis, 2003), Sea Piracy and Security Challenges of Maritime Business Operation in Bayelsa State, Nigeria: An Empirical Study (Essien \& Stephen, 2015), The Effect of Maritime Security Regime in World Supply of Seafarers (Gonlielmos \& Alexandros, 2014), Indonesian Sea Power and Regional Maritime Security Challenges (Marsetio, 2017).

This research is organized as follows, chapter 1 introduction, chapter 2 shows material and methods, chapter 3 shows the results of data and discussion, chapter 4 conclusion.

\section{MATERIAL AND METHODS 2.1. The Concept of Role Theory.}

Role theory is a theory that is a combination of theory, orientation, and scientific discipline, apart from psychology, role theory starts from and is still used in sociology and anthropology (Sarwono, 2002). In all three of these sciences, the term "role" is taken from the world of theater. In theater, an actor must play as a certain character and in his position as a character, he expects to behave in a certain way. It is from this perspective that role theories are composed. According to Biddle and Thomas (1966), role theory is divided into four groups, namely those concerning a). People who take part in social interactions; b). Behavior that appears in the interaction; c). Position of people in behavior; d). The link between people and behavior. Actors become aware of the social structure they occupy, therefore an actor tries to always appear "qualified" and is perceived by other actors as "not deviating" from the existing hope system in society (Sheryl \& Blackwell, 2004).

\subsection{The Concept of Naval Base Function}

One of the principal tasks of naval strategy in peacetime is to build or acquire a sufficient of naval and air bases to allow one's forces to accomplish national and military strategic objectives in wartime (Dwi, 2018). The main purpose of a naval base in general is to provide shelter, repair and supply for the ship and rest and recreation for the crews, to act as a focus of power as close to the potential adversary as possible, to serve as part of the screen to warn against an enemy attack, and to ensure control of one's own ship (Pfouts, 2007). This means that the main purpose of a naval base in general is to provide shelter, repairs and supplies for ships and rest and recreation for the crew, to act as a focus of force as close as possible to potential enemies, to be part of the sail, to warn against enemy attacks, and to ensure control of his own ship.

\subsection{The Concept of Naval Trinity}

According to Ken Booth, the naval Trinity theory as a major part of universal sea power has an important role, namely: the role of the military, the role of the police and the role of diplomacy. 


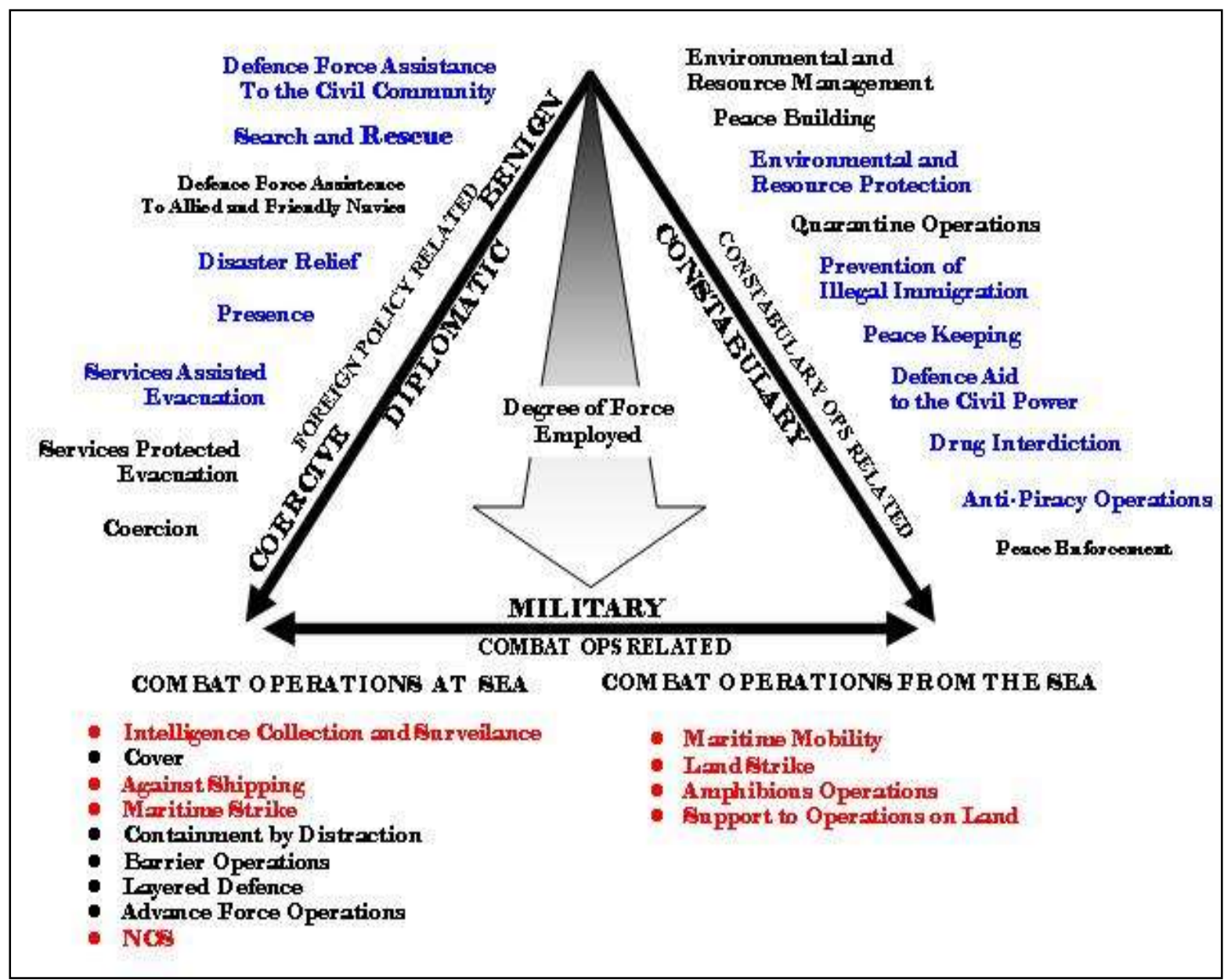

Figure 1. The Concept of Naval Trinity

The Navy Trinity Theory is used in this study because Bravo Naval base is a state security institution in its task of enforcing state sovereignty at sea and also carrying out patrols by existing warships means to enforce the law at sea, protect national marine resources and strength, maintain order at sea, and support national development by contributing to national stability and development in the work area of Bravo area especially in ALKI I.

\subsection{Sea Power Theory.}

A.T. Mahan said that in building a country that has a large Navy force, 6 (six) main elements needed as the main capital are: a). Geographical position, b). Build the face of the earth, c). An area, d). Community Character, e). Total population, f). Governmental Character. A.T. Mahan underlined, that Sea Power is a very important element for the glory of a nation. Besides that, the strength of the Navy is the main requirement to make a big, strong and advanced country (Giok, 2014). Perpetrators of state defense operations at sea consist of commercial fleets, navy, and bases (Wei \& Ahmed, 2015).

According to Marsetio (2014: 89), that Sea Power can be interpreted as a country that has a reliable Navy force and also means a country's ability to use and control the sea (sea control) and prevent opponents using it (sea denial).

\subsection{The Concept of Law Enforcement.}

According to Soekanto (1979), the meaning of law enforcement lies in the activity of harmonizing the relationships of values that are set out in the rules that are solid and embodying and acting as a series of translation of the final stage of values, to create, preserve and maintain peaceful social relations (Polinsky \& Shavell, 2000) (McLaughlin, 2016). The main problem of law enforcement lies in the factors that influence it including:

a. The legal factor, itself is the law. 
b. Law enforcement factors, namely those who form and apply the law.

c. Factors of facilities or facilities that support law enforcement.

d. Community factors, namely the environment in which the law applies or is applied.

e. Cultural factors, namely as a result of work, creativity, and taste based on the human initiative in the association of life.

This law enforcement theory is related to research questions concerning the function of Lanal Bravo in carrying out advanced law enforcement and elements of warships or patrol facilities used at sea to be used as law enforcement at sea.

\subsection{Strategy Management.}

The strategy is a word with a lot of meaning and everything is relevant and useful to those who are tasked with setting strategies for companies, businesses, or organizations. The strategy comes from Greek, namely Stratego, which is defined as a plan to destroy the enemy by using resources effectively (Rastislav \& Silvia, 2015 ).

Management strategies can be defined as the art and science in formulating, implementing, and evaluating cross-functional decisions that enable organizations to achieve their goals. This definition implies that strategic management focuses on integrating management, marketing, finance/accounting, production/operations, research and development, and information systems to achieve organizational success. The term strategic management in this text is used synonymously with the term strategic planning. The latter term is more often used in the business world, while the first is often used in the academic world.

\subsection{The Research Methodology.}

To solve problems in the observed research, steps are needed and determined to describe the approach and model of the problem. The steps taken are (1) Initial Identification of the element of Bravo Naval Base, (2) Study Literature, (3) Data Collection, (4) Data Processing, (5) Data Analysis, and (6) Interpretative of Conclusion.

$\rightarrow$ Target:

The purpose of this research is to determine the function of the base owned by Bravo Naval base in support of marine security operations.

\section{$\rightarrow$ Steps:}

The step of this research is Step 1 to identify problems by looking at internal and external factors, Step 2 conducting the analysis, Step 3 analyzing, and Step 4 giving suggestions for improvement and conclusions.

\subsection{NVivo Software}

NVivo is a software program used for qualitative and mixed-methods research. Specifically, it is used for the analysis of the unstructured text, audio, video, and image data, including (but not limited to) interviews, focus groups, surveys, social media, and journal articles. It is produced by QSR International. As of July 2014, it is available for both Windows and Macintosh operating systems.

Nvivo can analyze and organize unstructured text, audio, video, or image data, playback ability for audio and video files, so that interviews can easily be transcribed in NVivo. Ability to capture social media data from Facebook, Twitter, and Linkedln using the NCapture browser plug-in. Import notes and captures from Evernote - great for field research. Import citations from EndNote, Mendeley, Zotero, or other bibliographic management software - great for literature reviews.

\subsection{SWOT Analysis.}

SWOT analysis is an analysis that emphasizes 4 aspects, namely Strength, Weakness, Opportunity, and Threat (Ommani, 2011). This SWOT analysis will identify internal and external factors of the Bravo Naval base development strategy so that potentials can be developed in the future and can overcome existing weaknesses. From the internal side, it can be seen the strengths or weaknesses that are owned for the development of Bravo Naval base, while from the external side there will be seen opportunities and threats from the outside, after identifying these factors the formulation of the strategy is done using the SWOT method.

\section{RESULT AND DISCUSSION}

\subsection{SWOT Analysis of Bravo Naval base.}

Managing the goals and objectives of the analysis and implementation of the SWOT analysis will determine what are the advantages and strategies for developing the Bravo Naval base and the opportunities that support the development of the Bravo Naval base and challenges that will enhance development.

\section{a. Strength}


The definition of Strength in a SWOT analysis is the strength or strength that exists in a company or organization that affects the strategic decision-making process. Strengths found in the development of Bravo Naval base are 1). Bravo is a Naval Base, 2). Having adequate patrol facilities, 3). Good supply support is not constrained, 4). Having good personnel care facilities, 5). Has good base facilities.

\section{b. Weakness}

The definition of Weakness in a SWOT analysis is a weakness that exists in a company or organization that affects the strategic decision-making process. Weakness found in the development of Bravo Naval base is 1). There is no pier for leaning patrol elements, so it must synergize with other agencies in terms of borrowing the pier, 2). There is no vessel repair facility so rely on workshops and other companies to carry out repairs, 3). The number of personnel is limited so that it has not been maximized in the service achievement of duties.

\section{c. Opportunity}

The definition of opportunity in a SWOT analysis is an opportunity that exists outside the company or organization that influences the strategic decision-making process. Opportunity found in the development of Bravo Naval base is 1). The synergy between related officials can run smoothly, 2). Bravo region is large enough so that it is possible to develop capabilities.

\section{d. Threat}

The definition of Threat in a SWOT analysis is a threat that exists outside the company or organization that influences the strategic decision-making process. Threats found in the development of Bravo Naval base are 1). illegal logging, 2). Illegal Mining, 3). Illegal Fishing, 4). Drug Smuggling, 5). the restricted area of operation.

Table 1. Matrix of SWOT

\begin{tabular}{|c|c|}
\hline Strength (S) & Opportunities (0) \\
\hline $\begin{array}{l}\text { 1). Bravo is a Naval Base } \\
\text { 2). Having adequate patrol facilities } \\
\text { 3). Good supply support is not constrained } \\
\text { 4). Having good personnel care facilities } \\
\text { 5). Has good base facilities }\end{array}$ & $\begin{array}{l}\text { 1). The synergy between related officials can } \\
\text { run smoothly } \\
\text { 2). Bravo region is large enough so that it is } \\
\text { possible to develop capabilities }\end{array}$ \\
\hline Weakness (W) & Threats (T) \\
\hline $\begin{array}{l}\text { 1). There is no pier for leaning patrol elements, } \\
\text { so it must synergize with other agencies in } \\
\text { term of borrowing the pier } \\
\text { 2). There is no vessel repair facility so rely on } \\
\text { workshops and other companies to carry out } \\
\text { repairs } \\
\text { 3). The number of personnel is limited so that } \\
\text { has not been maximized in the service } \\
\text { achievement of duties }\end{array}$ & $\begin{array}{l}\text { 1). Illegal Logging } \\
\text { 2). Illegal Mining } \\
\text { 3). Illegal Fishing } \\
\text { 4). Drug Smuggling } \\
\text { 5). The restricted area of operation }\end{array}$ \\
\hline
\end{tabular}

Based on data analysis of strengths, weaknesses, opportunities, and threats that have been obtained, the strategic approach is as follows: Strenght - Opportunities use existing forces to create opportunities, Strength -
Threats use existing forces to avoid and eliminate threats - threats, Weakness Opportunities eliminate weaknesses to create opportunities, Weakness - Threat eliminates weaknesses to avoid threats.

Table 2. Matrix of Strategy Approach

\begin{tabular}{|c|l|l|}
\hline & \multicolumn{1}{|c|}{ S } & \multicolumn{1}{|c|}{ W } \\
\hline & \multicolumn{1}{|c|}{ Strategy S-O } & \multicolumn{1}{c|}{ Strategy W-O } \\
\hline $\mathbf{0}$ & $\begin{array}{l}\text { 1). Carry out coordination with agency officials related to } \\
\text { the use of landing facilities and repair } \\
\text { 2). Increase supply support efforts to make it more }\end{array}$ & $\begin{array}{l}\text { 1). Coordinate with agency } \\
\text { officials related to the use of } \\
\text { port facilities }\end{array}$ \\
\hline
\end{tabular}




\begin{tabular}{|l|l|l|}
\hline $\begin{array}{l}\text { effective and efficient } \\
\text { 3). Utilize existing base facilities to establish synergy } \\
\text { between relevant officials }\end{array}$ & $\begin{array}{l}\text { 2). Coordinate with } \\
\text { workshops and companies } \\
\text { related to shipping repair } \\
\text { facilities } \\
\text { 3). Propose the construction } \\
\text { of port and maintenance } \\
\text { workshops to ensure } \\
\text { operational service. }\end{array}$ \\
\hline \multicolumn{1}{|c|}{ Strategy S-T } & \multicolumn{1}{|c|}{ Strategy W-T } \\
\hline $\mathbf{T}$ & $\begin{array}{l}\text { 1). Carry out marine security operations routinely in } \\
\text { countering various threats of violations and crimes at } \\
\text { sea } \\
\text { 2). Carry out maritime potential development of coastal } \\
\text { communities about the dangers of the drug, illegal } \\
\text { fishing, illegal mining, illegal logging } \\
\text { 3). Maximize the coverage area of the sea security } \\
\text { operations by existing regulations }\end{array}$ & $\begin{array}{l}\text { 1). Carry out marine security } \\
\text { operations by maximizing } \\
\text { 2). Carry out the distribution } \\
\text { of personnel to optimize the } \\
\text { implementation of the } \\
\text { operations } \\
\text { 3). Optimizing the use of } \\
\text { docks and repair facilities } \\
\text { from outside to support } \\
\text { marine security operations. }\end{array}$ \\
\hline
\end{tabular}

Based on the SWOT matrix analysis in Table 3.2 above, we can compile several combination strategies to obtain priority that can be implemented in the effort of developing Bravo Naval base to support marine security operations in ALKI 1, namely:

\section{a. Strategy 1.}

Carry out coordination with agency officials related to the use of landing facilities and repairs. This can be done by creating an MOU with officials related to port facilities and when repairs. Besides that, there are also some innovative activities which basically can minimize the gap between related officials in Bravo.

\section{b. Strategy 2.}

Propose the construction of ports and maintenance workshops to ensure operational services. This can be done by submitting to Srena Mabesal through the RKA-KL to include the budget for the construction of dock facilities and repair facilities to support marine security operations, where the threat is increasingly complex.

\section{c. Strategy 3.}

Coordinate with workshops and companies related to shipping repair facilities. This can be done utilizing Bravo Naval base, making a cooperation with several competent workshops in the repair of ships so that if there are vessels that need repairs can be immediately handled effectively and efficiently.

\section{d. Strategy 4.}

Carry out maritime potential development of coastal communities about the dangers of drugs, illegal fishing, illegal mining, illegal logging. This can be done utilizing Bravo Naval base, making innovative activities aimed at enhancing the development of maritime potential involving coastal communities with local governments in counteracting all crimes and violations of the law such as illegal logging, illegal mining, illegal fishing and the danger of drug smuggling.

\section{e. Strategy 5.}

Maximizing the coverage area of the sea security operations under existing regulations. This can be done utilizing Bravo Naval base applying and complying with all regulations restricting the operation area and carrying out operations in the permitted area with maximum effort.

\section{CONCLUSION}

From some of the above, conclusions can be drawn from the development of the Pacific Islands Naval base to support marine security operations in ALKI 1, namely: 1). Carry out coordination with agency officials related to the use of landing facilities and repairs. 2). Propose the construction of ports and maintenance 
workshops to ensure operational services. 3). Coordinate with workshops and companies related to shipping repair facilities. 4). Carry out maritime potential development of coastal communities about the dangers of drugs, illegal fishing, illegal mining, illegal logging. 5). Maximizing the coverage area of the sea security operations following existing regulations.

\section{ACKNOWLEDGEMENT}

The authors greatly acknowledge the support from Indonesian Naval Command and Staff College, Sea Operation Magister Study Program, Seskoal Jakarta for providing necessary resources to carry out this research work. The authors are also grateful to the anonymous reviewers and journal editorial board for their many insightful comments, which have significantly improved this article.

\section{REFERENCES}

Avis, P. (2003). Surveillance And Canadian Maritime Domestic Security. Canadian Military Journal, 9-14.

Bueger, C. (2015). Learning from Piracy: Future Challenges of Maritime Security Governance. Economic and Social Research, 1-10.

dwi, N. (2018). Role of The Indonesian Navy Task Unit to Supporting Technology Transfer of Submarine By DSME South Korea-PT. Pal Indonesia. Asro Journal STTAL, 74-85.

Essien, \& Stephen, B. (2015). Sea Piracy and Security Challenges of Maritime Business Operation in Bayelsa State, Nigeria: An Empirical Study. International Journal of Humanities and Social Science, 213-221.

Feldt, L., Roell, D. P., \& Thiele, R. D. (2013). Maritime Security - Perspectives for a Comprehensive Approach. ISPSW Strategy Series: Focus on Defense and International Security, 1-25.

Giok, K. K. (2014). Sea Power As A Strategic Domain. Journal of The Singapore Armed Forces, 1-14.

Gonlielmos, \& Alexandros. (2014). The Effect of Maritime Security Regime in World Supply of Seafarers. Journal of Economics and Business, 63-77.
Heribertus, Budiyanto, \& Riduwan. (2018). The Management of Indonesian Navy Personnel Based on Competence to Achieve More Optimum Performance. IJSRM, 448-455.

Marsetio. (2017). Indonesian Sea Power and Regional Maritime Security Challenges. JMSNI, 1-11.

McLaughlin, R. (2016). Authorizations for Maritime Law Enforcement Operation. International Review of the Red Cross, 465-490.

Mustika, A., \& Aditya, M. K. (2017). Regional Maritime Cooperation in Maintaining Maritime Security and Stability: A test case for ASEAN unity andCentrally. Journal of ASEAN Studies, 119-134.

Ommani, A. R. (2011). Strengths, weaknesses, opportunities, and threats (SWOT) analysis for farming system businesses management: Case of wheat farmers of Shadervan District, Shoushtar Township, Iran. African Journal of Business Management Vol. 5(22), pp. 9448-9454, 30 September 2011, 94489454.

Pfouts, R. W. (2007). An Empirical Testing of the Economic Base Theory. Journal of American Institute of Planner, 64-69.

Polinsky, A. M., \& Shavell, S. (2000). The Economic Theory of Public Enforcement of Law. Journal of Economic Literature, 45-76.

Pujiyono. (2015). Reconstruction Of Indonesian Criminal Justice System In The Perspective Of The Judicial Power Independence. International Journal of Business, Economics, and Law, 59-66.

Rastislav, R., \& Silvia, L. ( 2015 ). Strategic Management of Business Performance Based on Innovations and Information Support in Specific Conditions of Slovakia. Journal of Competitiveness, 321.

Sheryl, \& Blackwell, S. (2004). Using Role Theory to Examine Determinants of Transformational and Transactional Leader Behavior. Journal of Leadership \& Organization, 1-10.

Wei, Z., \& Ahmed, S. (2015). A General Review of the History of China's Sea Power Theory Development. Naval War College Review, 1-14. 